FEDERAL RESERVE BANK OF SAN FRANCISCO

WORKING PAPER SERIES

\title{
Do Countries Default in "Bad Times"?
}

\author{
Michael Tomz \\ Department of Political Science, Stanford University \\ Mark L. J. Wright \\ Department of Economics, University of California, Los \\ Angeles
}

May 2007

Working Paper 2007-17

http://www.frbsf.org/publications/economics/papers/2006/wp07-17bk.pdf

The views in this paper are solely the responsibility of the authors and should not be interpreted as reflecting the views of the Federal Reserve Bank of San Francisco or the Board of Governors of the Federal Reserve System. This paper was produced under the auspices of the Center for Pacific Basin Studies within the Economic Research Department of the Federal Reserve Bank of San Francisco. 
May 25, 2007

\title{
Do Countries Default in "Bad Times"?
}

\author{
Michael Tomz* \\ Department of Political Science, Stanford University
}

Mark L. J. Wright*

Department of Economics, University of California, Los Angeles

\begin{abstract}
This paper uses a new dataset to study the relationship between economic output and sovereign default for the period 1820-2004. We find a negative but surprisingly weak relationship between output and default. Throughout history, countries have indeed defaulted during bad times (when output was relatively low), but they have also maintained debt service in the face of severe adverse shocks, and they have defaulted when domestic economic conditions were favorable. We show that this constitutes a puzzle for standard theories, which predict a much tighter negative relationship as default provides partial insurance against declines in output.
\end{abstract}

*We thank Gita Gopinath for sharing her MATLAB code, and Cristina Arellano, Aart Kraay, Guido Sandleris and Jeromin Zettlemeyer for helpful comments. Further comments welcome. A shorter version of this paper appeared as: Michael Tomz and Mark L. J. Wright. 2007. "Do Countries Default in "Bad Times"?" Journal of the European Economic Association, 5:2-3, pp. 352-60. 


\section{Introduction}

What is the relationship between sovereign default and economic activity in the defaulting country? Do sovereign countries default only in "bad times," when output is low? The answers to these questions are instructive as to whether sovereign default is a purely opportunistic phenomenon, in which a sovereign seizes the most resources for itself, or whether default conveys partial insurance against adverse economic outcomes. In turn, these issues have implications for the welfare effects of changing how supranational institutions and creditor country governments approach debt crises.

Towards an answer to these questions, this paper studies the relationship between sovereign default and economic activity for the period 1820-2004. Using a new data set of borrowing, defaults and economic activity, we summarize the relationship between economic activity and default. We find that regardless of the measure of association used, there exists a broad tendency for countries to default more often in "bad times" than in "good times." The relationship is weak, however: output often declines without a default being observed, and countries occasionally default when output is high.

We then contrast these empirical findings with the predictions of several widely-used models of sovereign default in the tradition of Eaton and Gersovitz (1981). In these models, markets are incomplete and default acts as a mechanism to provide costly partial insurance against declines in output. We show that, for a range of parameter values, these models predict a much stronger relationship between default and economic activity than occurs in the historical record. Taken together, our findings are consistent with the coexistence of both excusable defaults (for insurance purposes) and inexcusable ones (for opportunistic reasons).

The rest of this paper is organized as follows. Section 2 introduces our data set and characterizes the empirical relationship between output and default. Section 3 contrasts this evidence with the implications of well-known models of default with incomplete markets. Section 4 concludes. The Appendix describes in more detail the sources and methods used in constructing our database, and in performing the numerical computations. 


\section{The Empirical Relationship Between Output and Default}

In this Section, we outline the main sources and methods used to construct our database of sovereign defaults and economic activity, and describe the methods used to assess the relationship between defaults and economic activity. Further details on both data construction and statistical methods have been relegated to the data appendix. We then present our findings about the historical relationship between economic activity and default.

\section{A. Data}

Any study of sovereign defaults must begin with a definition of precisely what is meant by the term "default". A sufficient condition for a default to have occurred is that a country not meet its obligations, either on paying interest or repaying principal, within any grace period specified. We also regard a country as having defaulted if it makes an exchange offer that "contains terms less favorable than the original issue" in the case of sovereign bonds, or if "a rescheduling of principal and/or interest is agreed to by creditors at less favorable terms than the original loan. Such rescheduling agreements covering short- and long-term bank debt are considered defaults even where, for legal or regulatory reasons, creditors deem forced rollover of principal to be voluntary" (Beers 2004). We restrict attention solely to debts incurred to private creditors, and thus exclude official credits. Consequently, our measure of default differs from the dates of Paris Club rescheduling agreements. We also limit attention to defaults of national governments, and exclude defaults by provinces or cities.

It is also necessary to define what is meant by the "start" of a default as well as what sequence of events triggers the "end" of a default. We consider defaults on both interest and principal of a debt, and date the start of a default to either the date of the first missed payment or rescheduling, or the date at which a country announces that it will stop servicing its debts. A default is defined to have ended when a majority of creditors agrees to a settlement with

the country. A country is defined to be in default in a given year if it was in default for any month of that year, with the exception of defaults that are settled in January of a given year which are assumed to imply that the country is not in default for that year. Data on defaults on bank loans is drawn from Beers (2004), while the dates of defaults on sovereign bonds 
were drawn from Beers (2004) for the modern period, Suter (1990) for the middle decades of the 20th Century, and from Duggan and Tomz (2006) for the 19th and early 20th Centuries.

By our definition, 106 countries defaulted a total of 250 times since the end of the Napoleonic Wars. The most common defaulters were Ecuador, Costa Rica, Mexico, Uruguay, and Venezuela, each of which experienced at least 8 distinct spells of default. Ecuador and Honduras stand as the most long-standing defaulters; beginning with their initial loans as members of the Central American Confederation in the 1820s, each has registered nearly 120 years in default. New defaults have occurred in every decade since the 1820s, and they were most common during the Latin American crisis of the 1980s, when more than 50 countries (about 40 percent of all nations that owed money to private foreign creditors) failed to pay in full on time. The largest defaults in present value terms were the Argentine default of 2001, which was associated with privately held debt instruments with a principal of $\$ 90$ billion and was even larger once deferred interest was included, and the Russian repudiation of 1918 which was valued at the time at 1.7 billion pounds sterling (although around half of these debts were held by other governments, including about 800 million pounds of inter-allied war debts).

As a measure of economic activity, we employ annual estimates of a country's real gross domestic product in local currency. For most of the post-war period, we use official estimates as collected by the World Bank and reported in their World Development Indicators database. These estimates are then extrapolated backwards in time using measures of gross domestic product collected from a variety of country-specific sources, many (but not all) of which are collected in the compendia of Maddison (2001) and of the Conference Board and Groningen Growth and Development Centre (2006).

To measure "good" and "bad" times in economic activity, we construct a measure of business cycles by comparing actual GDP with Hodrick-Prescott filtered trend GDP. There is a considerable amount of debate as to which value of the Hodrick-Prescott smoothing parameter to use with annual data. Following the lead of Dolado, Sebastian and Valles (1993), Correia, Neves and Rebelo (1992) and Cooley and Ohanian (1991) we focus on a value of 400 , but also verify that our results are robust to using other commonly proposed values such as 6.25 (Ravn and Uhlig 2004; See also Baxter and King 1999 and Maravall and 
del Rio 2001), and 100 (Backus and Kehoe 1992, Giorno et al. 1995 and European Central Bank 2000).

In our analysis, we restrict attention to countries that actually owed debts to private foreign creditors, and therefore had the potential to default. To do this, we obtained estimates of the stock of debt owed by the government of a country to foreign private sector creditors, excluding trade creditors, for the period 1970 to the present from the World Bank's Global Development Finance. These were used to construct an indicator variable for years in which a country was a debtor, which was then taken back through the interwar period using estimates of bond issuance from the Adler Sovereign Bond Database. For the period before 1914, borrowers were identified through a comprehensive search of archival and secondary sources for six major capital markets - Amsterdam, Berlin, Frankfurt, London, New York, and Paris - as discussed in Tomz (2007).

\section{B. Measuring the Relationship Between Output and Default}

To begin, we visually examine the data for some well known defaulting countries. Figure One presents a graph of default dates and business cycles for Chile, a country for which we have an especially long series of output data. Following the expulsion of Spanish forces in 1818, Chile was quick to borrow in European financial markets, and just as quick to default in 1826. This was followed by three further default episodes in 1880, during the Great Depression in 1931, and during the Latin American debt crisis in 1983. It is obvious from the Figure that the relationship between output and default is quite weak. Although the latter two defaults coincided with very bad times for the Chilean economy, with drops in output by between 15 and 25 per-cent below trend being recorded, the two earlier episodes of default began with output above trend and, in the 1880 case, substantially so (more than 10 per-cent above trend). Moreover, there were numerous occasions in which output fell sharply and Chile did not default: output was more than 20 per-cent below trend in 1921, and more than 10 per-cent below trend in 1877, 1903 and 1975, and yet in not one of these cases did Chile default. Nor is this pattern due to the fact that Chile stopped borrowing. Although we do not have precise figures on the quantities of foreign debt owed by the Chilean government, we do know that it was an international debtor for the entire period under study, 
and moreover during the years 1865 to 1915 (the golden age of international finance), during which there were five sharp economic downtowns (more than five per-cent below trend) but only one default (and that was in a boom year), Chilean debt levels increased steadily.

Figure Two presents a comparable picture for Argentina. Like Chile, Argentina was quick to both borrow and default in the years after independence in 1816. This was followed by further defaults in 1890, the Latin American debt crisis in 1982, and again recently in 2001. The last three of these defaults, which are the only ones for which we have output data, were all associated with economic downturns; thus, unlike the case of Chile, bad economic conditions appeared to be necessary, if not sufficient, for a default to occur in Argentina. However, during its most severe economic downturns, Argentina did not default. For example, Argentina's 1890 default coincided closely with a decline in output to 16 per-cent below trend in 1891, while the 2001 default was associated with output being 13 per-cent below trend in 2002. However, declines in output of 21 per-cent below trend in 1881, 12 per-cent in both 1897 and 1902, 24 per-cent below trend in 1917, nine per-cent in 1932 during the Great Depression, and 12 per-cent in 1963, did not result in default, despite the fact that Argentina was one of the world biggest borrowers at both the end of the 19th century and the start of the 20th. Moreover, default appears to have preceded the worst output falls: the default in 1982 occurred when output was 3 per-cent below trend; it was not until 1985 that output dropped 9 per-cent below, and not until 1990 that it reached 20 per-cent below trend.

Next we examine whether these patterns hold up more systematically over a larger sample of countries. Combining our database of economic conditions and market access with our list of defaults, we have data for 175 sovereign entities covering 169 defaults, which lasted a total of 1,597 years. Seventy-five countries never defaulted. Although we have data on output for 13,118 country-years, only 9,244 of these observations coincided with a country that was a borrower: in some cases we have output data for a country before it borrowed for the first time, and in others the country redeemed all of its debts and did not borrow for a period of time.

As a first cut, we computed the contemporaneous correlation between our indicator variable for default, and our measure of the business cycle. As shown in Table 1, when computed for our entire sample, the correlation coefficient is -0.08 . The correlation coefficient 
rises to -0.11 when it is computed on the subsample of countries that default at least once over the period. Independently of the sample of countries, these results imply a negative but weak relationship. The low correlation between default and output is understandable in light of the graphical examples above. Countries like Argentina and Chile have often maintained debt service in the face of adverse shocks; they have also defaulted during relatively good times, or remained in default long after output has recovered. However, it is also possible that, because default is an qualitative variable taking on values of only one and zero while our measure of business cycles is a quantitative variable, the correlation coefficient understates the relationship between default and output.

To address this issue, we computed two alternative measures: the average deviation from trend and the proportion of years in which output was below trend. Table 2 shows that, on average, defaults began when output was about 1.6 percentage points below trend, and that economic performance remained about 1.4 points below trend during the entire default episode. (We focus on estimates in which the smoothing parameter is 400, but results are similar when other values for this parameter are used). In contrast, output typically matched trend in the first year after a default, and was about two-tenths of a point above trend during non-default years. Table One also shows that roughly sixty-two per-cent of the 169 default episodes began in "bad times." Moreover, output was below trend a majority of years during which the defaults persisted. In contrast, output was typically above trend in periods of non-default, including the year immediately after a country settled its arrears. Taken together, these estimates confirm that defaults are more common in bad times than in good.

Nonetheless, the relationship is surprisingly weak. In more than 39 percent of all observations $(.473 \times 7657 / 9244)$, countries managed to avoid default even though output was below trend, whereas in nearly 44 percent of all default-years, countries remained in default even though output had surged above trend. Our estimates further imply that more than one-third of defaults began during "good times," and that more than half of defaults ended during bad times (see the column labeled "last year of default," which indicates the year in which debtors settled their arrears with creditors.)

But perhaps defaults occur only when output drops severely? To explore this possibil- 
ity, we sorted the data according to the depth of the economic downturn. Table 3 shows that defaults were about twice as likely during the most severe economic contractions (more than 7 percent below trend) than during other periods. This finding lends support to a negative but nonlinear relationship between output and default. Even so, the same data also show that only one-third of debtors lapsed into default when falling on extremely hard times, and that roughly one-fifth defaulted while experiencing a boom period in which output exceeded trend by more than 10 percentage points. The results are similar if we restrict attention to the first year of a default; although 4.3 per-cent of countries which experienced a recession more than 7 per-cent below trend defaulted in that year, 2.3 per-cent of countries experiencing a boom of more than 7 per-cent above trend also defaulted that same year.

Finally, Table 4, which has three panels containing results for each value of the HodrickPrescott smoothing parameter, assesses the robustness of these results to changing the time period under study, and varying the sample of countries to exclude developed countries. Focusing on the results for a smoothing parameter of 400 in Table 4A, we find that defaults were more likely to occur in good times during the 19th Century, although this finding is based on data from only eleven default episodes. In the interwar period, more than three quarters of all defaults began when output was below trend, reflecting the wave of defaults that coincided with the Great Depression. For the modern period, results are very similar to those for the entire sample, reflecting the fact that three quarters of our data comes from this period. Varying the sample of countries by income or population has little impact on the results.

\section{Lessons for Theory and Policy}

The empirical results described above confirm our intuition that defaults tend to be associated with adverse economic conditions. However, the relationship is quite weak: countries sometimes default when economic conditions are strong, and often do not default when output is low even though they have substantial stocks of external debt. These findings are also potentially troubling to the extent that many of our theoretical efforts aimed at understanding sovereign defaults are designed to reproduce a strong negative correlation between default and output. To examine this, we contrast our empirical findings with the predictions 
of a class of models of sovereign default based on the pioneering work of Eaton and Gersovitz (1981). In this class of models, markets are incomplete consisting only of one period nonstate-contingent bonds. Default is costly in the sense of leading to a period of exclusion from international financial markets; default may also have a direct adverse effect on the level of economic activity in the country. Default consequently provides (costly) insurance against negative shocks to economic activity. This insurance feature implies that default should occur most often when economic conditions are weak.

We focus on the model of sovereign default used by Aguiar and Gopinath (2006), which shares some elements with recent papers by Arellano (2005) and Yue (2006). Specifically, consider a country represented by an agent with preferences over state contingent consumption sequences given by

$$
E_{0} \sum_{t=0}^{\infty} \beta^{t} \frac{c_{t}^{1-\sigma}-1}{1-\sigma}
$$

for some $\sigma>0$. Each period, the country receives an exogenous endowment of the single non-storable consumption good $y_{t}$ which evolves stochastically according to

$$
\ln y_{t}=\ln \Gamma_{t}+z_{t}
$$

Here, $\Gamma_{t}$ represents a stochastic trend in output which evolves according to

$$
\ln \Gamma_{t+1}=\ln \Gamma_{t}+\ln g_{t+1}
$$

and where the growth rate in this trend follows

$$
\ln g_{t+1}=\left(1-\rho_{g}\right)\left(\ln \mu_{g}-\frac{1}{2} \frac{\sigma_{g}^{2}}{1-\rho_{g}^{2}}\right)+\rho_{g} \ln g_{t}+\varepsilon_{g t+1} \quad \text { where } \varepsilon_{g t+1} \sim N\left(0, \sigma_{g}^{2}\right)
$$

Alternatively, $z_{t}$ captures transitory movements in output and evolves according to

$$
z_{t+1}=\mu_{z}\left(1-\rho_{z}\right)+\rho_{z} z_{t}+\varepsilon_{z t+1} \quad \text { where } \varepsilon_{z t+1} \sim N\left(0, \sigma_{z}^{2}\right)
$$


Each period $t$ begins with the country owning a (possibly negative) stock of foreign bonds $a_{t}$ which represent a claim to one unit of the consumption good. If the country decides to default, they are excluded from international capital markets (this is not uncontroversial; see, for example, Wright 2002 and the references cited therein). As long as the country is out of international markets, they cannot smooth their consumption. Moreover, it is assumed that they lose a fraction $\delta$ of their output endowment. Exclusion from financial markets ends with probability $\lambda$ each period, at which point output returns to normal and the country can access international capital markets starting with zero debts. A country with access to capital markets can smooth its consumption by trading in foreign bonds at price $q_{t}$.

The model is closed by specifying that international capital markets are populated by a large number of risk neutral investors facing an opportunity cost of their funds given by $r^{*}$. Given a probability of default as a function of assets given by $\pi\left(a_{t}\right)$ (to be determined endogenously), investors will lend to a country at the nonlinear price $q\left(a_{t}\right)=\left(1-\pi\left(a_{t}\right)\right) /\left(1+r^{*}\right)$.

Aguiar and Gopinath (2006) consider two versions of this framework. The first version shares the approach of Arellano (2005) and others in focusing on movements in output that, while persistent, are ultimately transitory movements about a deterministic trend so that $\ln g_{t}$ is a constant. The main innovation of their paper is to additionally examine a version of this model in which stochastic movements in the growth rate of the economy are the only force driving output fluctuations (so that $z_{t}=0$ for all $t$ ). We solve both versions of the model numerically using the algorithm described in Arellano (2005). Parameter values are as specified in Tables 3A and 3B of Aguiar and Gopinath, modified for an annual frequency of observation as described in the appendix. We simulate the model for 4,000 years and extract the last 2000 years to eliminate the effects of initial conditions. Results are presented for different values of the smoothing parameter, and are averaged over 100 simulations (simulations in which no default occurred are discarded in computing moments conditional on default).

Table 5 presents results for both versions of the model for all the empirical moments we have emphasized. As a result of the low annual discount factor, both versions of the model support relatively little debt in equilibrium compared to what is observed in the data: as discount rates are high, the threat of future punishments has less impact in deterring default, and creditors lend little in equilibrium. In the modle with permanent shocks, countries default 
about twice a Century which is close to the frequency observed in the data. However, the model with transitory shocks produce very little default: on the order of once every two millenia. Further, the model has been calibrated to produce defaults lasting only two and half years on average which, although closer to the data for last ten years, is much too short to match the long-run historical data.

How should we expect the model to perform on the dimensions studied in the data above? As the model has two state variables - debt and output (on in the case of permanent shocks, output growth) - the model does not imply a one to one relationship between output and defaults; the relationship also depends non-linearly on debt levels. Nonetheless, the relationship predicted by both versions of the model for default and output is much tighter than the relationship found in the data. As shown in Table 6, for the permanent shock model the contemporaneous correlation between output and default is around -0.2 which is more than twice the level found in the historical data. The transitory shock model produces a much lower correlation in line with the data, but only as a result of it producing far fewer defaults than the permanent shock model, or than found in the historical record. The much stronger negative relationship emerges even more clearly in Table 7 which shows that, for the model with transitory shocks, every default begins when output is below trend, while in the permanent shock model between 85 per-cent and 100 per-cent of defaults begin in bad times. As the model is parameterized to produce defaults lasting on average two and onehalf years, output has little time to recover during a default, leading the model to generate the prediction that between 75 and 85 per-cent of all default years should be below trend. Output is also dramatically below trend during defaults. In the transitory shock model, defaults begin when output is a startling 41 per-cent below its trend level, while even in the permanent shock version, output is more than seven per-cent below trend. During a default, output stays between fifteen and twenty per-cent below trend in the stationary model, and between three and six per-cent below trend with permanent shocks.

In summary, the baseline parameterization of both versions of the model produce a relationship between default and output that is much tighter than that exhibited in the data: output falls more in default than is observed, and almost all default years are associated with output levels below trend. The role of default in the model as providing insurance against 
output declines hard wires a strong negative correlation between output and default in the first year of a default for all parameter values.

It is conceivable that the models predictions for the relationship between output and default more generally may be improved by calibrating the model with a lower settlement probability and with a lower output cost of default. Both Aguiar and Gopinath (2005) and Yue (2005) postulate a direct output cost of default of two per-cent in their theoretical work in response to estimates by Sturzenegger (2002) of the output costs of defaults. As we have seen, when the direct output cost of default is combined with the tendency to only default when output is below trend, the model often produces a level of output, conditional on being in default, as much as twenty per-cent below trend. However, in our empirical work above, we found that in default the output of a country is, on average, only 1.5 per-cent below trend, while when it is in good standing it is on average two tenths of one per-cent above trend. That is, in order to match the data, the direct output cost of default in the model cannot be larger than (and probably needs to be much less than) 1.7 per-cent. Moreover, for other values of the Hodrick-Prescott smoothing parameter, output is found to be no more than (and in some cases much less than) one per-cent lower during a default. This leads us to investigate the effect of reducing the direct output cost of a default one-hundred-fold. We also calibrate the annual settlement probability such that defaults last on average 10.1 years, which is the average length of a default in our historical data set.

Table 5 shows that the effect of these changes is to drastically reduce the amount of debt that a country is allowed to accumulate; the threat of longer exclusion period from financial markets is dwarfed by the cost of losing a larger fraction of the countries output. Table 5 also shows that countries default much less often; in the permanent shock model, only once every 150 years. In the transitory shock model, no defaults were recorded in our two-thousand year simulations. As shown in Table 9, and confining attention to the permanent shock model, countries now stay in default long enough for output to rise back above trend; sixty five per-cent of default years are now below trend, which is almost exactly the proportion found in the data. However, because defaults still tend to begin when output is very far below trend, the average level of output in the year a default begins is 8 per-cent for the permanent shock model compared to less than two per-cent in the data. 


\section{Conclusions}

In this paper, we have provided the first long-run analysis of the relationship between default and economic performance. Our analysis is based on a new data set on borrowing, defaults and economic activity for a large number of countries since 1820. We estimate a negative but surprisingly weak relationship between default and economic activity. Throughout history, countries have indeed defaulted during bad times, but they have also maintained debt service in the face of severe adverse shocks, and they have defaulted when domestic economic conditions were highly favorable. This pattern is puzzling, not only because it seems inconsistent with the conventional wisdom that countries default in response to adverse economic conditions, but also because it stands at odds with prominent models in which default provides costly insurance against economic adversity.

It is possible that a different definition of "bad times" for an economy would produce results more in line with the conventional wisdom. For example, although the HodrickPrescott filter is by far the most widely used technique for constructing business cycles, it may be that a stronger negative relationship could be found by using a band pass filter, or by using a filter based on growth rates of output, such as the Bry-Boschan filter advocated by Harding and Pagan (2002). Another possibility is that, as suggested by Levi-Yeyati and Panizza (2006), the relationship between defaults and output is different when measured at quarterly as opposed to annual frequencies. However, our preliminary results suggest that our findings are robust to using other filtering methods, while an inspection of the examples presented in Figure 1 of Levi-Yeyati and Panizza (2006) reveals that the measure of bad times is the same regardless of whether quarterly or annual data is used.

It is important to remember, however, that regardless of whether or not alternative methods can restore a strong negative relationship between default and output in the data, our findings demonstrate an inconsistency between our theories and the data. Consequently, we need to revise our models of sovereign debt. We offer three conjectures for future work. First, defaults may provide insurance, not against variation in aggregate output as implied by current models, but instead against fluctuations in some narrower component of economic activity. For example, default may be the optimal response to severe declines in exports, 
government revenues, or the output of the tradeables sector. Likewise, default may help countries cope with increases in the cost of capital, and would therefore be more likely to occur when world interest rates rise.

A second direction for research would explore the interaction between domestic and international forces. Perhaps defaults offer the most relief when economic downturns cannot be smoothed by additional borrowing. By this logic, one would expect a contingent relationship between output and default: countries respond to domestic recessions by borrowing when global capital markets are flush, and by defaulting when adverse conditions in international markets make additional borrowing difficult, if not impossible. New models, built on these premises, could help explain the otherwise puzzling fact that declines in output trigger default in some historical episodes but not in others. Models of this class could also explain why, over the past two centuries, defaults have occurred in waves, with the largest surges in the 1820s, 1870s, 1890s, 1930s, and 1980s (see, e.g., Suter 1992 and Tomz 2007). These waves, we conjecture, occurred when recessions in borrowing countries coincided with contractions in key creditor nations. Recent theoretical work has begun to explore these possibilities. For example, Miller, Tomz and Wright (2006) develop a model in which defaults occur when international gains from trade are low either because economic conditions are adverse or because world interest rates are high. The implications of these models should be tested against the long-run historical record.

Finally, more energy should be devoted to developing mixed-motive models of default. Many defaults over the past two centuries have coincided with dramatic collapses in economic activity, and therefore seem consistent with default as a form of insurance. A notable proportion of defaults occurred during good times, however, when economic circumstances at home clearly would not warrant a lapse of payments. As Tomz (2007) notes, many of these seemingly inexcusable defaults occurred when political upheavals brought new coalitions to power that favored default for opportunistic or ideological reasons. A model of default that includes not only on economic but also political shocks - that incorporates not only good and bad times, but also good and bad governments - could account for significantly more of the historical record than models that are currently available.

These conjectures, if valid, could have important policy implications. There has been 
much debate in recent years about how to reduce the frequency and costs of sovereign default (see, for example, Pitchford and Wright 2006 and the references therein). Research on the economic and political sources of default could help leaders prevent defaults, or at least forecast them more accurately and address their root causes. Research could also specify the likely consequences of making defaults less costly. To the extent that defaults arise for opportunistic reasons, and not simply as a way to smooth consumption, policymakers should exercise caution in reducing the costs of default. After all, such efforts could have the perverse effect of encouraging opportunistic lapses of payment. The results in this paper not only advance our understanding of key theoretical issues in the literature, but they also lay a foundation for empirically-informed improvements to the international financial architecture. 


\section{Data Appendix: Concepts, Sources and Methods}

This appendix outlines the way we define defaults, as well as the methods used and main data sources consulted in constructing our database

\section{A. Economic Activity}

The output series was constructed from 36 sources, which are listed below. When combining data from different sources, we used the following algorithm.

1. We dropped parts of any output series in which the economic growth rate remained nearly constant for at least four successive years, because these records were almost certainly based on interpolation between fixed points, rather than genuine measures of economic performance from one year to the next. Our precise rule was as follows. Let $s$ index sources of information, $c$ index countries, and $t$ index time periods. Define $g_{s, c, t}=100\left(G D P_{s, c, t}-G D P_{s, c, t-1}\right) / G D P_{s, c, t-1}$, where $t$ indexes years. If $\sum_{n=0}^{3}\left(\mid g_{s, c, t-n}-\right.$ $\left.g_{s, c, t-n-1} \mid<.2\right)=4$, implying four successive periods in which growth in one period was within two-tenths of one percentage point of growth in the previous period, then delete observations $G D P_{s, c, t-1}$ to $G D P_{s, c, t-4}$.

2. We established a hierarchy of sources, which dictated which sources took precedence when more than one source had information for a given country in a given year. Table Eleven presents the hierarchy and indicates how many datapoints were ultimately drawn from each source.

The country-specific sources were as follows: Argentina: Cortés Conde (1997). Austria: Schulze (2000). Austria-Hungary: Schulze (2000). Brazil: Goldsmith (1986). Chile: Braun (2000). Colombia: GRECO (2002). Ecuador: Banco Central del Ecuador (1997). Egypt: Hansen and Marzouk (1965); Yousef (2002). Germany: Hoffmann (1965); Maddison (1995). Greece: Kostelenos (forthcoming). Hungary: Eckstein (1995); Schulze (2000). Iceland: Gunnarsson (1990); Statistics Iceland (2005). Korea: Mizoguchi (1988). Mexico: INEGI (1985). New Zealand: Greasley (2000); Rankin (1992). Norway: Grytten (2004). Pakistan: Federal Bureau of Statistics - Pakistan (1997). Portugal: César das Neves (1994); Lains (2003). Rhodesia: Commission of 
Enquiry (1945). Russia: Gregory (1982). Taiwan: Mizoguchi (1988). United States: Carter (2006).

3. For each country, we constructed a consistent time series by working backward in time from the year 2004 to the year 1820. Each element $c, t$ in the time series was filled by one of the following four algorithms, in priority order.

(a) Extrapolation without gaps. If $G D P_{c, t+1}$ has already been filled, let $s$ be the highest-ranking source that gives both $G D P_{s, c, t}$ and $G D P_{s, c, t+1}$. Assign $G D P_{c, t}=$ $\left(G D P_{c, t+1}\right)\left(G D P_{s, c, t}\right) /\left(G D P_{s, c, t+1}\right)$. ELSE

(b) Extrapolation with gaps using the last-used source. Find the minimum $n$ such that $G D P_{c, t+n}$ has already been filled. Let $s$ be the source that was used to fill that cell. If source $s$ gives both $G D P_{s, c, t}$ and $G D P_{s, c, t+n}$, assign $G D P_{c, t}=$ $\left(G D P_{c, t+n}\right)\left(G D P_{s, c, t}\right) /\left(G D P_{s, c, t+n}\right)$. ELSE

(c) Extrapolation with gaps using a different source. Find the highest-ranking source $s$ that gives both $G D P_{s, c, t}$ and $G D P_{s, c, t+n}$, where $G D P_{c, t+n}$ was filled by a source other than $s$. Find the minimum $n$ that satisfies this condition, and assign $G D P_{c, t}=\left(G D P_{c, t+n}\right)\left(G D P_{s, c, t}\right) /\left(G D P_{s, c, t+n}\right)$. ELSE

(d) Initiate a new series. Find the highest-ranking source $s$ that gives $G D P_{s, c, t}$, and assign $G D P_{c, t}=G D P_{s, c, t}$. This creates a series break, since the unit of measurement in $G D P_{c, t}$ will not necessarily match the units in $G D P_{c, t+n}$, where $n \geq 1$.

4. Finally, our measure of good times was constructed by applying the Hodrick-Prescott filter. Attention was restricted to series in which in which data are expressed in comparable units for at least 10 consecutive years. Note that, due to series breaks, some countries will have more than one time series, e.g. one series before World War I and a second series after World War I. HP calculations were done in Stata 9.2 using the hprescott procedure, which was written by Kit Baum. 


\section{B. Debtors}

Only borrowers can default, and so we restricted our analysis to years for which a country was a debtor in gross terms. To do this, we constructed an indicator variable that took on the value of one if a country had debts outstanding in a given year, and zero otherwise. Measures of borrowing were derived from a number of sources. For the period 1970 to the present, data on developing countries was taken from the debtor reporting system of the World Bank as summarized in their Global Development Finance publication. We focused entirely on public and publicly guaranteed debt in the form of either bank loans of bonds (that is, trade credit was excluded). For South Korea, which no longer participates in the debtor reporting system, historical issues of Global Development Finance were used.

There were some additional issues that had to be confronted concerning the period from 1970-2004 and data from Global Development Finance. These include:

1. In some cases, Standard and Poors lists a country as being in default on bank loans in the period 1970-2004 despite the fact that Global Development Finance does not list the country as having any outstanding long-term public or publicly guaranteed loans due to commercial banks. However, Global Development Finance often includes entries for either principal or interest arrears from private creditors for this period (this figure is not divided into bonds, bank loans, or other debts). In these cases, we assume that some of the arrears were on debts to commercial banks and list borrower dates as the dates of amounts in arrears. This affected the following countries: Albania (19912004), Burkina Faso (1992-2002), Cape Verde (1986-1997, 1999-2004), Central African Republic (1970-2004), Ethiopia (1991-92), Guinea (1970-77, 1998-2004), Guinea-Bissau (1984-2000), Iran (1992), Mauritania (1985-95, 1999). Mozambique (2000-2004), Niger (1975, 1991-1993), Sao Tome and Principe (1986-1994), Sierra Leone (1973, 1995-2000, 2003-4), Togo (1970-72),

2. Croatia and Macedonia are listed as being in default in 1992, and having arrears in 1993, the first year that they appear in Global Development Finance. We code them as having debts in 1992.

3. In some cases, a country is listed by Standard and Poors as being in default on bank 
loans at a time before the country reported debts to Global Development Finance. In these cases, we code the country as having amounts outstanding for the exact years that they are listed in default. This may omit some years in which the country was a borrower prior to the default. This affected the following countries and years: Angola (1985-1988), Bosnia and Herzegovina (1992-1997),

4. In some cases, a country is listed by Standard and Poors as being in default on bank loans at a time before the country reported positive debts to Global Development Finance. In these cases, we code the country as having amounts outstanding for the exact years that they are listed in default. This may omit some years in which the country was a borrower prior to the default. This affected the following countries: Cape Verde (1981-1986), Iran (1978-79), Mozambique (1980, 1983), Vietnam (1985-1988). In the case of Iran, this problem was also addressed using data from the Adler Sovereign Bond Database as described below.

5. In some cases, a country is listed by Standard and Poors as being in default on bank loans but is not a member of the debtor reporting system. In the absence of other measures of bank debt outstanding, we code the country as having amounts outstanding for the exact years that they are listed in default. This may omit some years in which the country was a borrower both prior to and after the default. This affected the following countries and years: Antigua and Barbuda (1996-2004), Cuba (1997-2004), East Germany (1971, 1978, 1982), Iraq (1987-2004), North Korea (1974-2004), Nauru (2002-2004), Slovenia (1992-1996), North Yemen (1985-1989)

6. In some cases, a country is listed in default for a year immediately after the last years that they are listed as having outstanding debts. It is possible that this discrepancy is due to time aggregation. Global Development Finance records debts in September of the relevant year, while we record defaults as occurring in the year if the country was in default for any month of the year (other than for settlements agreed to in January). In this case, we code the country as being a borrower for that year. This affected: Mauritania (1996), Togo (1997).

For developed countries for 1914 to 2004, and for developing countries for the period 1914 to 1970, the primary source of data on amounts outstanding was the Adler Sovereign 
Bond Database. In some cases, the amount outstanding data for a bond was missing. This was resolved in a number of ways:

1. When amount outstanding data were reported for the same bond for non-consecutive years, the amounts were interpolated.

2. When amount outstanding data were not available beyond certain years, but price data were available for these bonds, a positive value for amount outstanding was recorded.

3. When amount outstanding data were not available beyond certain years, and price data were not available for these bonds, a positive value for amount outstanding was recorded if the bond terms implied that the bond had not matured and there was no record of a default or early redemption of debt.

In a small number of cases, questions remained after this process was complete. In some cases, these questions could be resolved by resort to alternative sources. In some cases, these questions remain unresolved. A list of these questionable cases includes:

1. Paraguay is recorded as having debts from the beginning of the debtor reporting system in 1970. The Adler database records bond debts up to and including 1966. The 1970 and 1971 Annual Reports of the World Bank records positive values for Paraguay's foreign debts from private creditors (not including trade credits) in 1968 and 1969. As a consequence, we implied a positive debt level for Paraguay for 1867.

2. Haiti, Barbados and Grenada are recorded as having positive levels of bond debt in 1970 according to the debtor reporting system. All are recorded as having zero bond debt in the Adler database of sovereign bonds for 1969. For these cases, zero values for debt were left unchanged prior to 1970.

3. Egypt is recorded as having positive commercial bank debt in 1970 according to the debtor reporting system, but no bond debt in 1970. According to the Adler database, it has no bond debt from 1963 to 1969. According to the World Bank publication Borrowing in International Capital Markets, Egypt did not enter into any new commercial bank loans in 1970. In this case, based on the assumption that commercial bank debt existed prior to 1970, positive values for debt have been interpolated. 
4. According to the debtor reporting service, Romania had no outstanding sovereign debt from private creditors for 1972-78 and 1989-91. However, the Adler database records Romania has having outstanding debts for all of these years. Although the debtor reporting service is generally considered to be the definitive source, because it relies on self-reporting by the debtor country, it may neglect debts which are in dispute between creditors and debtors. We elected to follow the Adler database in this case.

5. The debtor reporting system records Iran as having no outstanding sovereign debts from private creditors from 1971 to 1979. The procedure described above for using the Adler database would impute positive values for these years as there are price data in 1981 for some older bonds which were supposed to have matured prior to this date. Standard and Poors record Iran as being in default on bank loans in 1978 and 1979. It is possible that bonds in default continued to be traded, but it seems more likely that this is a data error. Hence, we impute positive debt levels for Iran for only the years 1978 and 1979.

For the period prior to 1914, we used the series described in Tomz (2007).

There were some inconsistencies between the data for the period before 1914, and that from 1914 onwards. In some cases, the difference was due to the fact that the Adler database focused upon bonds issued in the 20th Century, and consequently ignored some bonds that were issued at the end of the 19th Century and that were still outstanding in the early 20th century. In these cases, we examined Moody's manuals for the period to cover any overlapping years. This was done for Saar, Poland, Czechoslovakia, Jamaica, Trinidad and Tobago, St Kitts and Nevis, Guadelope, Martinique, Guyana, Bolivia, Luxembourg, Germany, French West Africa, Nigeria, South Africa, Madagascar, Mauritius, Morocco, Algeria, and Tunisia. In other cases, the difference was due to the fact that the Adler database excludes bonds issued in the home currency, or issued at home, even if those bonds were traded overseas and were actively held by foreigners. In such cases, which includes a number of well known net creditors (but gross debtors) such as the United Kingdom, France, and the United States, we included them as debtors.

A few remaining special cases included: 
1. The Adler database excludes some bond issues by Newfoundland on the grounds, apparently, that Newfoundland was a province of Canada, despite the fact that it was autonomous until the 1940's.

2. The Adler database sometimes mislabels bonds from the Belgian Congo (or Congo Kinshasa) as bonds from the French Congo (or Congo - Brazzaville). This misclassification was resolved by reference to Moody's manuals.

3. Data on bondholdings by Cape Colony, Natal and Transvaal are excluded after 1910 on the basis of their becoming provinces of South Africa.

4. The Adler database misclassifies some debts of British Honduras (Belize) as debts of Honduras. This was resolved by reference to Moody's manuals.

5. The Adler database does not list any bonds for Austria-Hungary. However, in the note sections of the database, some bonds are listed as being Austro-Hungarian bonds that were later divided amongst Austria and Hungary. We use these bonds to infer that the Hapsburgs owed debts until 1918.

\section{Defaults}

We define a country to be in default in a given year if it was in default for any part of that year. A default is defined to have begun at the time that any interest or amortization payment was missed, or at the time any change in payment terms was announced, whichever comes first. A default is defined to end at the time in which creditors agree to a settlement with the debtor. If a settlement is agreed in January of the relevant year, then the country is recorded as not being in default for that year. In a small number of cases, a country settles old debts and then defaults again in the same year. Our work treates these incidents as part of the original default event.

The primary source for information on defaults in the latter part of the 20th Century is the collection of default dates by Standard and Poors (Beers 2003, 2004). This source gives dates for defaults on both foreign currency bond debt, and on commercial bank loans. There have been substantial changes in the default dates for some countries between the 2003 and 2004 editions of this publication. In all cases we have followed the 2004 edition. 
Prior to 1985, Standard and Poors rely on the work of Suter $(1990,1992)$ in constructing default dates. We follow Suter (1990) only for the post war period. Instead, for the 19th Century, and for early part of the 20th Century, our primary source is Duggan and Tomz (2006), while for the interwar period we rely on a range of different sources. In many cases, the list of default dates that we derive is identical to that provided by Suter (1992). However, there are a number of instances in which we find defaults to have begun or ended in different years, while there are also a number of cases in which we find that defaults listed by Suter did not occur altogether. Some of these discrepancies may be due to different conventions in coding (for example, using an indicator for default status on a particular date for each year, or coding the end of a default at the date the government proposed final terms), while others appear to be the result of different interpretations of the available evidence. There are also a small number of unresolved questions regarding the dating of some of the defaults.

A list of these cases, as well as a description of some special cases that were not easily classified, follows, along with a brief description of our reasoning. More information on these defaults can be found in Duggan and Tomz (2006).

\section{Austria 1868-1871}

We found that this default ended in 1871, as opposed to 1870 , because newspaper reports in The Times of London 12th December 1871 refer to the fact that a settlement had not yet been reached, while reports on 28th December make reference to a settlement which had "just been effected."

2. Bolivia 1875-1880

We found that this default ended one year later when the Corporation of Foreign Bondholders reported that long-standing litigation returned funds to bondholders

We do not record the delayed interest payment of 1874 (the "lock box" episode) as a default.

3. Brazil 1826-29

We found that Brazil was not in default on foreign borrowing from 1826 to 1829. This is a complicated episode where various sources disagree as to whether or not there was an actual default and, if there was a default, whether or not it extended to foreign debts. Even Suter (1990) differs from Suter (1992), where the former only lists 1826-27 
as a default. Ultimately, we excluded this episode based on a number of contemporary sources, cited in Duggan and Tomz (2006) which indicate that Brazil did not default on foreign loans from 1826-7, and on the fact that any default in 1828-9 involved at most one obligation of the Portuguese government, which were assumed by Brazil as part of diplomatic negotiations with European powers, and where repayments were deferred only due to the secession crisis in Portugal.

4. Bulgaria 1932-1985

We follow Suter (1990) in ending this default in 1985. However, no documentation is provided to justify the choice of this date.

5. Chile 1880-1884

We found that this default ended in 1884 , as opposed to 1883 , because the missed sinking fund drawings were made up beginning with the drawing in January 1885 .

6. China 1939-1949

We follow Suter (1990), although other sources use a later date.

7. Colombia 1848-61, 1877, 1879-1896, 1900-1905

We found that the default of 1848-61 began two years earlier because the first interest payment was missed on 1st June 1848.

We added the default of 1877 when payments were suspended because of an insurrection. The arrears were liquidated in January of 1878.

We found that the default of 1879-1896 started in 1879 because the July 1879 coupon, which was payable in October, was the first payment missed.

We found that the default of 1900-1905 ended in 1905 because in April of that year agreement was reached with the Corporation of Foreign Bondholders. Suter (1990) also lists an end date of 1905 .

8. Costa Rica 1828-1844

We found that this default ended in 1844 because bondholders only voted to accept the offer of 1840 in April of 1844.

9. Cuba 1960

Other sources date the end of this default much later. We follow Suter (1990).

10. Czechoslovakia 1959-1960 
We follow Suter (1990), although other sources date the end of this default much later.

11. Dominican Republic 1899-1908

We found that the default of 1899-1908 ended one year later because it was not until 1908 that French and Belgian bondholders voted to accept the settlement arising from the treaty of 1907 .

12. Ecuador 1868-1891, and 1894-1899

We found that the default of 1868-91 ended one year later because the bondholder meeting of 1890 added stipulations to the governments offer. It was not until 1891 that bondholders accepted the original offer.

We found that the default of 1894-99 ended one year later because the last agreement was negotiated with bondholders in March 1899 after three years of previous negotiations.

13. El Salvador 1897-1899

We found that this default began one year earlier and ended one year later than Suter's estimates of 1898 . The 1897 start date refers to the missed amortization payments in November of that year, while the 1899 end date refers to the negotiated settlement of February that year.

14. Greece 1894-1898

We found that this default ended in 1898 because the final convention was signed in March of 1898.

15. Guatemala 1894-1895, and 1898-1913

We found that the 1894-1895 default ended on year later because bondholders voted to accept the agreement in may of 1895.

We found that the 1898-1913 default started one year earlier as bondholders agreed to reschedule debts in November of 1898. This was then followed by an outright default on the rescheduled debts in 1899.

16. Honduras 1871-1925

We found that this default started two years earlier because of missed amortization payments in 1871. The first coupon payments were missed in 1873.

17. Liberia 1874-1899 
We found that the default of 1874-1899 started and ended one year earlier because the August 1874 coupons were not paid, while bondholders agreed to accept terms in March of 1899 .

18. Ottoman Empire 1875-1881

We do not include the short delays in interest payments in 1866, 1871 and 1874 as defaults.

We found that the 1875-1881 default began one year earlier because an amortization payment was missed in May of 1875.

19. Paraguay $1892-96$

We found that the default of 1892-96 ended one year later as bondholders ratified the settlement in April 1896.

20. Peru $1876-1890$

We found that this default ended in 1890 when bondholders met and accepted the agreement.

21. Russia 1918

We follow Suter (1990) and Beers (2003, 2004) who record the Russian repudiation as starting and ending in 1918. Other sources date the end of this default much later.

22. Spain 1823-1834, 1836-1867, and 1872-1882

We found that the default of 1823-1834 began one year earlier because the loans were repudiated in October and the first coupon payment was missed in November 1823.

We found that the default of 1836-1867 began one year earlier because coupon payments were missed in November of 1836 .

We corrected a typographical error that appears in both Suter (1992) and Beers (2003, 2004) concerning the start of the 1872 default episode.

23. Tunisia 1878-1884

We add this default episode. Coupon payments were missed, or not paid in full, in 1878, 1879, 1880 and 1881. The default ends in 1884 when France assumes these debts.

24. Uruguay $1875-1878$

We found that this default started one year earlier when a November amortization payment was missed. 
25. Venezuela 1847-59, 1864-1880, and 1892-1893

We found that the default of 1847-59 started one year earlier when the October 1847 coupon payment was missed.

We found that the default of 1864-1880 started one year earlier and ended one year later. The default was announced in December 1874. Although proposed in January of 1880, the settlement was not accepted by bondholders until February. We do not consider the partial settlement of 1876 to constitute an end of the default.

We found that the default of 1892-1893 ended one year later because payments were resumed in June 1893 (this is in line with Suter 1990, but not Suter 1992).

\section{Other Variables}

1. "Rich" and "poor" countries in 2000, 1950, 1915, 1870 and 1820

These indicator variables were constructed using data on GDP per capita at PPP's taken from Maddison (2002). In order to control, as much as possible, for selection bias, we divided the sample according to whether countries were "rich" in 2000, 1950, 1915, 1870 and 1820. In all years but 1950, we defined a country to be "rich" if its income per capita was at least half as large as the income per capita of the richest country. For 1820, the richest country in Maddison's data set was the Netherlands; in 1870 it was Australia; in 1915 and 2000 it was the USA. In 1950, the richest countries in the world were Qatar, Kuwait and the United Arab Emirates, with Maddison estimating Qatar to have a level of income per capita roughly three times as large as in the United States. Hence for 1950, we define a country as being rich if its income per capita was no less than half the level of the United States.

We defined a country to be "poor" in two alternative ways. First, we define a country to be poor if it is not "rich." This assumes that if Maddison does not have an estimate of a country's income per capita in a given year, it is poor. This is probably reasonable given that richer countries tend to have more comprehensive historical data. Second, and alternatively, we define a country to be poor if Maddison has data for that country in the relevant year, and it is not rich by our criterion. We refer to these alternative 
measures as Poor (1) and Poor (2) in the tables, respectively.

\section{Interest Rates}

The main creditor countries for the period under study were the United Kingdom, and the United States of America. We constructed measures of the tightness of credit markets in these countries using interest rate series constructed by Global Financial Data. For the United Kingdom we used the yield on a 2.5\% consol (file IGGBRCY), while for the United States we used the yield on 10 year government bond which have been calculated to ensuring a constant maturity (file IGUSA10Y). Both of these series were available for the entire period under study, and in both cases we use yields on 31st December of the relevant year.

\section{Inflation Rates}

Ex post real interest rates were constructed by subtracting the rate of inflation from the nominal interest rate series discussed above. For the United Kingdom we use a retail price index series (file CPGBRY) while for the United States we use a consumer price index (file CPUSAY)

\section{Money Supplies}

Data on the nominal stock of money, defined as M2, was obtained from Warren Weber. 


\section{Numerical Appendix}

To match the predictions of the theories of sovereign default proposed by Eaton and Gersovitz, Arrelano and Aguiar and Gopinath, we need to adapt their calibrations to annual frequency. There is some controversy about how this should be done. We describe our procedure below. The resulting parameter values are collected in Table 10.

\section{A. Redemption Probability}

If $\lambda^{Q}$ is the probability of a default ending in a quarter, then the probability of the default ending in one year is

$$
\begin{aligned}
\lambda^{A} & =\lambda^{Q}+\lambda^{Q}\left(1-\lambda^{Q}\right)+\lambda^{Q}\left(1-\lambda^{Q}\right)^{2}+\lambda^{Q}\left(1-\lambda^{Q}\right)^{3} \\
& =\lambda^{Q}\left[1+\left(1-\lambda^{Q}\right)+\left(1-\lambda^{Q}\right)^{2}+\left(1-\lambda^{Q}\right)^{3}\right] .
\end{aligned}
$$

\section{B. Discount and Interest Rates}

If the representative agent for a country discounts consumption next quarter at a rate given by $\beta^{Q}$, then the discount rate for one year can be determined from

$$
\beta^{A}=\left(\beta^{Q}\right)^{4}
$$

Annual interest rates are given in turn from

$$
\left(1+r^{A}\right)=\left(1+r^{Q}\right)^{4}
$$

\section{Stochastic Processes}

Given a stochastic process of the form

$$
y_{t+1}=\phi y_{t}+\varepsilon_{t+1}
$$

where $t$ indexes quarters, we can find

$$
y_{t+4}=\phi^{4} y_{t}+\hat{\varepsilon}_{t+4},
$$


where

$$
\hat{\varepsilon}_{t+4}=\phi^{3} \varepsilon_{t+1}+\phi^{2} \varepsilon_{t+2}+\phi \varepsilon_{t+3}+\varepsilon_{t+4} .
$$

Hence, if annual output is constructed by cumulating four quarters of output flows, we have

$$
\begin{aligned}
y_{s+1}^{A} & =y_{t+4}+y_{t+3}+y_{t+2}+y_{t+1} \\
& =\phi^{4}\left(y_{t}+y_{t-1}+y_{t-2}+y_{t-3}\right)+\hat{\varepsilon}_{t+4}+\hat{\varepsilon}_{t+3}+\hat{\varepsilon}_{t+2}+\hat{\varepsilon}_{t+1} \\
& =\phi^{4}\left(y_{t}+y_{t-1}+y_{t-2}+y_{t-3}\right)+\hat{\varepsilon}_{s+1}^{a} \\
& =\phi^{4} y_{s}^{A}+\hat{\varepsilon}_{s+1}^{A},
\end{aligned}
$$

where $s$ indexes years, and where

$$
\begin{aligned}
\hat{\varepsilon}_{s+1}^{A} & =\hat{\varepsilon}_{t+4}+\hat{\varepsilon}_{t+3}+\hat{\varepsilon}_{t+2}+\hat{\varepsilon}_{t+1} \\
& =\varepsilon_{t+4}+(1+\phi) \varepsilon_{t+3}+\left(1+\phi+\phi^{2}\right) \varepsilon_{t+2}+\left(1+\phi+\phi^{2}+\phi^{3}\right) \varepsilon_{t+1} \\
& +\left(\phi+\phi^{2}+\phi^{3}\right) \varepsilon_{t}+\left(\phi^{2}+\phi^{3}\right) \varepsilon_{t-1}+\phi^{3} \varepsilon_{t-2} .
\end{aligned}
$$

Note that this imparts a moving average component to the innovations in this equation. For simplicity, we will abstract from this moving average component, and adjust only the autocorrelation parameter and the variance of the innovations

$$
\begin{aligned}
\sigma_{\hat{\varepsilon}^{a}} & =\sigma_{\varepsilon}\left[1+(1+\phi)^{2}+\left(1+\phi+\phi^{2}\right)^{2}+\left(1+\phi+\phi^{2}+\phi^{3}\right)^{2}\right. \\
& \left.+\left(\phi+\phi^{2}+\phi^{3}\right)^{2}+\left(\phi^{2}+\phi^{3}\right)^{2}+\phi^{6}\right]^{1 / 2} .
\end{aligned}
$$


Table One: Historical Correlations between Default and Leads/Lags of Output Shocks

\begin{tabular}{c|cccccc}
\hline \hline \multirow{2}{*}{ Output Lead/Lag } & \multicolumn{3}{|c}{ Whole Sample } & \multicolumn{3}{c}{ Defaulting Countries } \\
& HP 400 & HP 100 & HP 6.25 & HP 400 & HP 100 & HP 6.25 \\
\hline-4 & 0.01 & 0.02 & 0.01 & 0.01 & 0.02 & 0.02 \\
-3 & -0.01 & 0.01 & 0.02 & -0.01 & 0.01 & 0.02 \\
-2 & -0.03 & -0.02 & 0.01 & -0.05 & -0.02 & 0.01 \\
-1 & -0.07 & -0.05 & -0.03 & -0.09 & -0.07 & -0.04 \\
0 & -0.08 & -0.06 & -0.03 & -0.11 & -0.08 & -0.04 \\
+1 & -0.07 & -0.05 & -0.01 & -0.10 & -0.06 & -0.01 \\
+2 & -0.07 & -0.04 & 0.00 & -0.09 & -0.05 & 0.00 \\
+3 & -0.06 & -0.03 & 0.01 & -0.08 & -0.03 & 0.01 \\
+4 & -0.05 & -0.02 & 0.00 & -0.07 & -0.03 & 0.00 \\
\hline \hline
\end{tabular}


Table Two: Historical Relationship between Output and Default

\begin{tabular}{|c|c|c|c|c|c|c|}
\hline & & & & First & Last & Year \\
\hline & & In & Not in & Year of & Year of & After \\
\hline & Total & Default & Default & Default & Default & Default \\
\hline \multirow[t]{2}{*}{ Country-Years (N) } & 9,244 & 1,597 & 7,657 & 169 & 160 & 150 \\
\hline & \multicolumn{6}{|c|}{ HP smoothing parameter $=400$} \\
\hline Country-Years Below Trend (\%) & 48.8 & 56.2 & 47.3 & 61.5 & 58.8 & 47.3 \\
\hline \multirow[t]{2}{*}{ Mean Deviation from Trend (\%) } & -0.1 & -1.4 & 0.2 & -1.6 & -1.3 & 0.0 \\
\hline & \multicolumn{6}{|c|}{ HP smoothing parameter $=100$} \\
\hline Country-Years Below Trend (\%) & 48.9 & 54.7 & 47.7 & 64.5 & 53.8 & 42.7 \\
\hline \multirow[t]{2}{*}{ Mean Deviation from Trend (\%) } & -0.1 & -0.9 & 0.1 & -1.7 & -0.7 & 0.3 \\
\hline & \multicolumn{6}{|c|}{ HP smoothing parameter $=6.25$} \\
\hline Country-Years Below Trend (\%) & 48.8 & 50.7 & 48.4 & 63.3 & 48.8 & 39.3 \\
\hline Mean Deviation from Trend (\%) & 0.0 & -0.3 & 0.0 & -1.5 & -0.1 & 0.5 \\
\hline
\end{tabular}


Table Three: Historical Default Rates, by Output Quantiles

\begin{tabular}{l|ccccccccc}
\hline \hline \multirow{2}{*}{ Size of Shock } & \multicolumn{3}{|c}{ HP 400} & & \multicolumn{3}{c}{ HP 100} & & \multicolumn{3}{c}{ HP 6.25} \\
& Cutoff & Default & Default & Cutoff & Default & Default & Cutoff & Default & Default \\
& & Rate & Initiation & & Rate & Initiation & & Rate & Initiation \\
& $(\%)$ & $(\%)$ & Rate $(\%)$ & $(\%)$ & $(\%)$ & Rate $(\%)$ & $(\%)$ & $(\%)$ & Rate $(\%)$ \\
\hline worst $5 \%$ & -11.0 & 32.0 & 4.3 & -9.0 & 31.5 & 4.8 & -5.5 & 29.9 & 5.2 \\
$5-10 \%$ & -7.0 & 29.3 & 4.3 & -5.7 & 25.3 & 3.7 & -3.5 & 20.7 & 3.9 \\
$10-25 \%$ & -2.8 & 19.6 & 2.5 & -2.3 & 18.7 & 3.0 & -1.4 & 17.7 & 2.4 \\
$25-50 \%$ & 0.1 & 15.3 & 1.3 & 0.1 & 15.7 & 1.3 & 0.1 & 14.8 & 1.4 \\
$50-75 \%$ & 3.0 & 12.7 & 1.0 & 2.5 & 12.7 & 0.7 & 1.5 & 15.1 & 1.3 \\
$75-90 \%$ & 6.9 & 16.2 & 1.4 & 5.5 & 17.0 & 1.5 & 3.6 & 16.6 & 1.2 \\
$90-95 \%$ & 10.1 & 15.9 & 2.4 & 8.2 & 16.9 & 1.9 & 5.2 & 20.3 & 1.5 \\
$95-100 \%$ & & 20.6 & 2.2 & & 22.5 & 2.4 & & 21.6 & 1.5 \\
\hline \hline
\end{tabular}


Table Four A: Robustness Checks (HP 400)

\begin{tabular}{|c|c|c|c|c|c|c|c|}
\hline & \multicolumn{3}{|c|}{ Number of } & \multicolumn{2}{|c|}{ Default Years } & \multicolumn{2}{|c|}{ Default Starts } \\
\hline & obs. & defaults & $\begin{array}{l}\text { default } \\
\text { years }\end{array}$ & $\begin{array}{c}\text { below } \\
\text { trend } \\
(\%)\end{array}$ & $\begin{array}{c}\text { trend } \\
\text { devn } \\
\text { (Ave \%) }\end{array}$ & $\begin{array}{c}\text { below } \\
\text { trend } \\
(\%)\end{array}$ & $\begin{array}{c}\text { trend } \\
\text { devn } \\
\text { (Ave \%) }\end{array}$ \\
\hline $1820-1869$ & 525 & 2 & 91 & 42.9 & 0.5 & 0.0 & 3.8 \\
\hline $1870-1913$ & 1,232 & 9 & 77 & 46.8 & 0.2 & 44.4 & -0.1 \\
\hline $1920-1938$ & 932 & 26 & 163 & 59.5 & -2.4 & 76.9 & -8.3 \\
\hline $1950-2004$ & 5,870 & 125 & 1,103 & 58.2 & -1.4 & 61.6 & -0.9 \\
\hline $1970-2004$ & 4,284 & 121 & 987 & 59.6 & -1.6 & 61.2 & -0.8 \\
\hline $1980-2004$ & 3,208 & 110 & 930 & 60.4 & -1.7 & 62.7 & -0.9 \\
\hline $1990-2004$ & 1,964 & 40 & 539 & 61.8 & -2.4 & 67.5 & -1.6 \\
\hline Poor (1) in 2000 & 6,638 & 163 & 1,534 & 56.9 & -1.4 & 63.2 & -2.0 \\
\hline Poor (1) in 1950 & 7,338 & 163 & 1,561 & 56.1 & -1.4 & 61.4 & -1.6 \\
\hline Poor (1) in 1913 & 7,066 & 151 & 1,489 & 55.8 & -1.3 & 60.3 & -1.2 \\
\hline Poor (1) in 1870 & 7,379 & 158 & 1,556 & 55.9 & -1.3 & 60.1 & -1.3 \\
\hline Poor (1) in 1820 & 7,346 & 162 & 1,515 & 57.1 & -1.5 & 63.0 & -1.9 \\
\hline Poor (2) in 2000 & 5,782 & 156 & 1,443 & 56.8 & -1.4 & 62.2 & -1.9 \\
\hline Poor (2) in 1950 & 6,261 & 148 & 1,434 & 55.4 & -1.4 & 61.5 & -1.7 \\
\hline Poor (2) in 1913 & 3,486 & 63 & 646 & 51.6 & -1.2 & 55.6 & -0.4 \\
\hline Poor (2) in 1870 & 3,417 & 59 & 609 & 52.2 & -1.3 & 54.2 & -0.2 \\
\hline Poor (2) in 1820 & 2,630 & 36 & 362 & 53.6 & -1.5 & 50.0 & 0.3 \\
\hline Population $>1 \mathrm{~m}$ & 8,685 & 162 & 1,536 & 56.0 & -1.5 & 61.1 & -1.7 \\
\hline
\end{tabular}


Table Four B: Robustness Checks (HP 100)

\begin{tabular}{|c|c|c|c|c|c|c|c|}
\hline & \multicolumn{3}{|c|}{ Number of } & \multicolumn{2}{|c|}{ Default Years } & \multicolumn{2}{|c|}{ Default Starts } \\
\hline & obs. & defaults & $\begin{array}{l}\text { default } \\
\text { years }\end{array}$ & $\begin{array}{c}\text { below } \\
\text { trend } \\
(\%)\end{array}$ & $\begin{array}{c}\text { trend } \\
\text { devn } \\
\text { (Ave \%) }\end{array}$ & $\begin{array}{c}\text { below } \\
\text { trend } \\
(\%)\end{array}$ & $\begin{array}{c}\text { trend } \\
\text { devn } \\
\text { (Ave \%) }\end{array}$ \\
\hline $1820-1869$ & 525 & 2 & 91 & 42.9 & 0.4 & 0.0 & 4.7 \\
\hline $1870-1913$ & 1,232 & 9 & 77 & 49.4 & 0.1 & 44.4 & -0.3 \\
\hline $1920-1938$ & 932 & 26 & 163 & 57.1 & -2.2 & 76.9 & -8.1 \\
\hline $1950-2004$ & 5,870 & 125 & 1,103 & 56.6 & -0.8 & 65.6 & -1.0 \\
\hline $1970-2004$ & 4,284 & 121 & 987 & 57.7 & -0.9 & 65.3 & -0.9 \\
\hline $1980-2004$ & 3,208 & 110 & 930 & 58.0 & -1.0 & 65.5 & -0.9 \\
\hline $1990-2004$ & 1,964 & 40 & 539 & 57.3 & -1.4 & 67.5 & -0.8 \\
\hline Poor (1) in 2000 & 6,638 & 163 & 1,534 & 55.3 & -0.9 & 66.3 & -2.1 \\
\hline Poor (1) in 1950 & 7,338 & 163 & 1,561 & 54.6 & -0.9 & 64.4 & -1.7 \\
\hline Poor (1) in 1913 & 7,066 & 151 & 1,489 & 54.6 & -0.8 & 64.2 & -1.3 \\
\hline Poor (1) in 1870 & 7,379 & 158 & 1,556 & 54.5 & -0.8 & 63.9 & -1.4 \\
\hline Poor (1) in 1820 & 7,346 & 162 & 1,515 & 55.3 & -0.9 & 66.1 & -2.0 \\
\hline Poor (2) in 2000 & 5,782 & 156 & 1,443 & 55.1 & -0.9 & 65.4 & -2.0 \\
\hline Poor (2) in 1950 & 6,261 & 148 & 1,434 & 53.8 & -0.8 & 64.2 & -1.8 \\
\hline Poor (2) in 1913 & 3,486 & 63 & 646 & 51.7 & -0.7 & 57.1 & -0.8 \\
\hline Poor (2) in 1870 & 3,417 & 59 & 609 & 51.9 & -0.8 & 55.9 & -0.5 \\
\hline Poor (2) in 1820 & 2,630 & 36 & 362 & 51.7 & -0.8 & 52.8 & 0.1 \\
\hline Population $>1 \mathrm{~m}$ & 8,685 & 162 & 1,536 & 54.8 & -0.9 & 64.2 & -1.8 \\
\hline
\end{tabular}


Table Four C: Robustness Checks (HP 6.25)

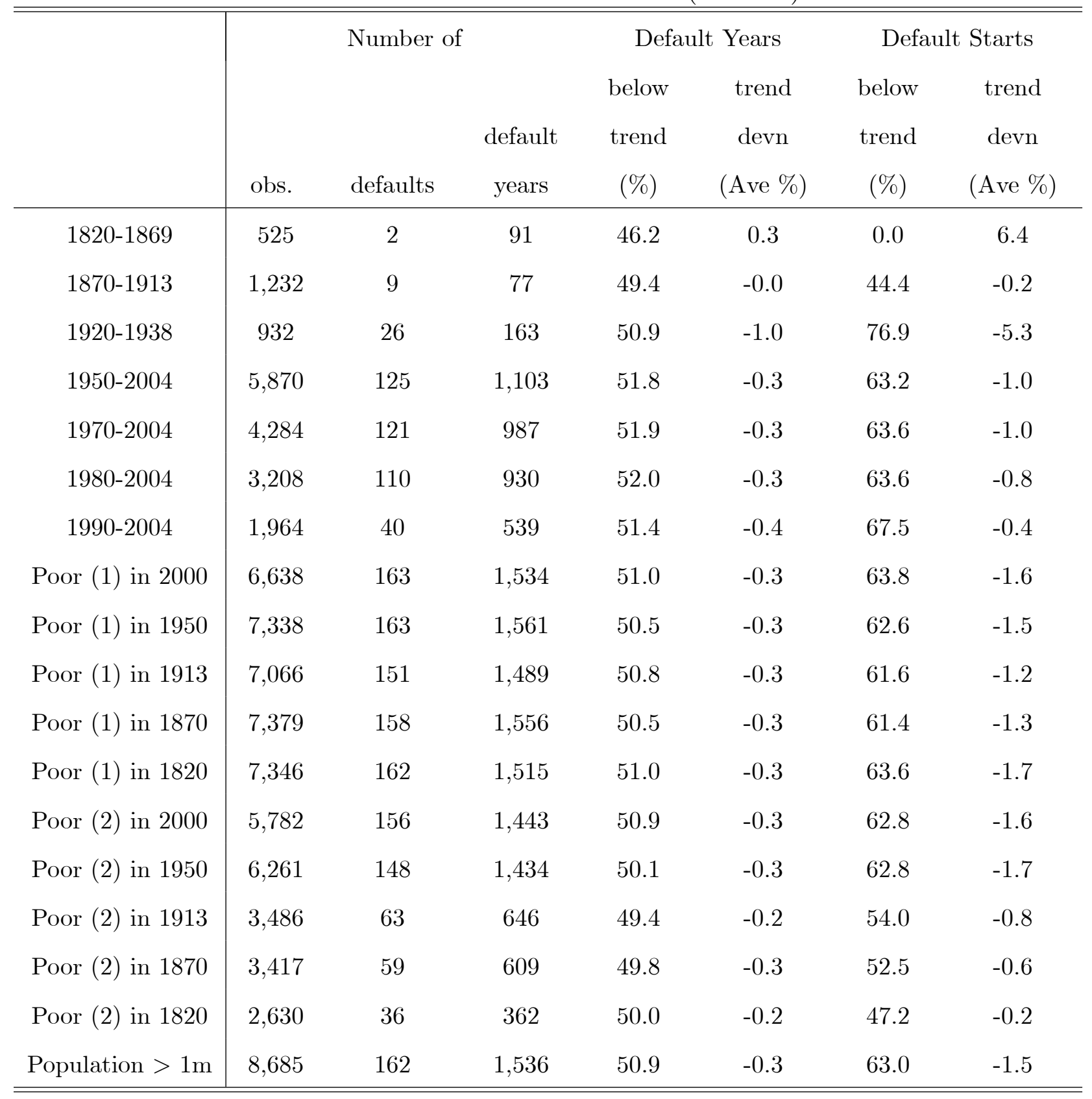


Table Five: Simulation Results for Debt and Default

\begin{tabular}{l|crcc}
\hline \hline & \multicolumn{2}{c}{$\begin{array}{r}\text { Transitory Shocks } \\
\text { Lower Cost }\end{array}$} & \multicolumn{2}{c}{$\begin{array}{c}\text { Permanent Shocks } \\
\text { Baseline }\end{array}$} \\
& Baseline & $\begin{array}{r}\text { Lower Cost } \\
\text { Long Defaults }\end{array}$ & & Long Defaults \\
\hline Debt/GDP (Ave \%) & 10.1 & 0.2 & 6.5 & 0.1 \\
Debt/GDP (Max \%) & 18.7 & 0.4 & 8.3 & 14.8 \\
Defaults (\# in 2000 years) & 1.3 & 0.0 & 42.4 & 149.9 \\
Years of Default (\# in 2000 years) & 3.6 & 0.0 & 121.3 & 7.5 \\
Years of Default (\% of years) & 0.2 & 0.0 & 6.1 & \\
\hline \hline
\end{tabular}


Table Six: Correlation Between Default and Output in Simulation

\begin{tabular}{l|cccccc}
\hline \hline \multirow{2}{*}{ Output Lead/Lag } & \multicolumn{3}{|c}{ Transitory Shocks } & \multicolumn{3}{c}{ Permanent Shocks } \\
\hline-4 & HP 400 & HP 100 & HP 6.25 & HP 400 & HP 100 & HP 6.25 \\
-3 & 0.02 & 0.02 & 0.01 & 0.11 & 0.10 & 0.04 \\
-2 & 0.02 & 0.02 & 0.02 & 0.10 & 0.10 & 0.07 \\
-1 & 0.01 & 0.02 & 0.02 & 0.06 & 0.07 & 0.08 \\
0 & -0.01 & -0.01 & 0.00 & -0.03 & -0.02 & 0.02 \\
+1 & -0.06 & -0.06 & -0.06 & -0.19 & -0.20 & -0.18 \\
+2 & -0.03 & -0.03 & -0.01 & -0.16 & -0.14 & -0.08 \\
+3 & -0.01 & -0.01 & 0.01 & -0.12 & -0.10 & -0.02 \\
+4 & -0.00 & 0.00 & 0.01 & -0.09 & -0.06 & 0.01 \\
\hline \hline
\end{tabular}


Table Seven: The Relationship Between Default and Output in Simulation

\begin{tabular}{l|cccccc}
\hline \hline & \multicolumn{3}{|c}{ Transitory Shocks } & \multicolumn{3}{c}{ Permanent Shocks } \\
& $\mathrm{HP}=400$ & $\mathrm{HP}=100$ & $\mathrm{HP}=6.25$ & $\mathrm{HP}=400$ & $\mathrm{HP}=100$ & $\mathrm{HP}=6.25$ \\
\hline Output in Default (Ave \% dev) & -25.7 & -23.9 & -17.8 & -5.6 & -4.6 & -3.1 \\
Output Not in Default (Ave \% dev) & 0.0 & 0.0 & 0.0 & 0.4 & 0.3 & 0.2 \\
Output in Default Start Year (Ave \% dev) & -41.6 & -39.7 & -33.4 & -7.4 & -7.2 & -6.3 \\
Output in Settlement Year (Ave \% dev) & -13.6 & -11.6 & -5.7 & -4.5 & -3.4 & -1.3 \\
Default Yrs Below Trend (\%) & 83.8 & 84.0 & 79.5 & 78.1 & 78.4 & 74.3 \\
Non Default Yrs Below Trend (\%) & 50.0 & 50.0 & 50.0 & 48.3 & 48.2 & 48.5 \\
Default Starts Below Trend (\%) & 100.0 & 100.0 & 100.0 & 85.9 & 90.1 & 96.6 \\
Settlements Above Trend (\%) & 24.5 & 22.4 & 26.4 & 27.1 & 29.7 & 38.2 \\
\hline \hline
\end{tabular}


Table Eight: Default and the Size of Output Declines in Simulation

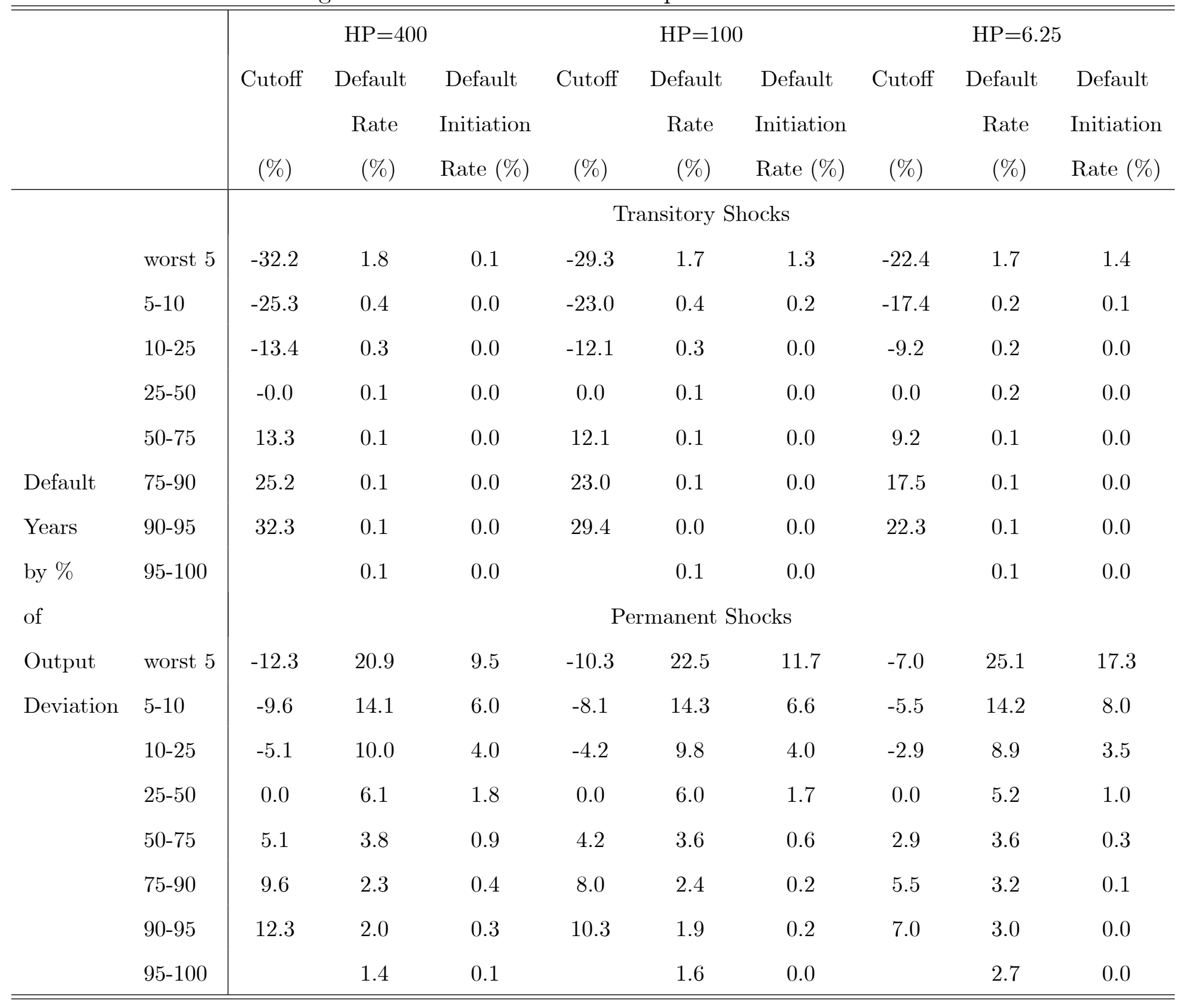


Table Nine: Default and Output when Defaults are Long

\begin{tabular}{l|cc}
\hline \hline & Transitory Shocks & Permanent Shocks \\
& \multicolumn{2}{|c}{ HP 400} \\
\hline Output in Default (Ave \% dev) & n.a. & -2.8 \\
Output Not in Default (Ave \% dev) & 0.0 & 0.2 \\
Output in Default Start Year (Ave \% dev) & n.a. & -8.4 \\
Output in Settlement Year (Ave \% dev) & n.a. & -2.0 \\
Default Yrs Below Trend $(\%)$ & n.a. & 63.6 \\
Non Default Yrs Below Trend $(\%)$ & 50.0 & 48.9 \\
Default Starts Below Trend $(\%)$ & n.a. & 88.8 \\
Settlements Above Trend $(\%)$ & n.a. & 40.7 \\
\hline \hline
\end{tabular}


Table Ten: Aguiar and Gopinath (2006) Baseline Parameter Values for Simulations

\begin{tabular}{lc|cccc}
\hline \hline & & \multicolumn{2}{c}{ Temporary Shocks } & \multicolumn{2}{c}{ Permanent Shocks } \\
& parameter & Quarterly & Annual & Quarterly & Annual \\
\hline Risk Aversion & $\gamma$ & 2 & 2 & 2 & 2 \\
Discount Factor & $\beta$ & 0.8 & 0.41 & 0.8 & 0.41 \\
World Interest Rate & $r^{*}$ & $1 \%$ & $4.1 \%$ & $1 \%$ & $4.1 \%$ \\
Loss of Output in Autarky & $\delta$ & $2 \%$ & $2 \%$ & $2 \%$ & $2 \%$ \\
Probability of Settlement & $\lambda$ & $10 \%$ & $34 \%$ & $10 \%$ & $34 \%$ \\
Mean Growth Rate & $\mu_{g}$ & 1.006 & 1.024 & 1.006 & 1.024 \\
Autocorrelation of Trend Growth & $\rho_{g}$ & n.a. & n.a. & 0.17 & 0.0008 \\
Standard Deviation of Trend Growth & $\sigma_{g}$ & n.a. & n.a. & $3 \%$ & 0.07 \\
Autocorrelation of Transitory Output & $\rho_{z}$ & 0.9 & 0.6561 & n.a. & n.a. \\
Standard Deviation of Transitory Output & $\sigma_{z}$ & 0.034 & 0.1942 & n.a. & n.a. \\
\hline \hline
\end{tabular}


Table Eleven: Prioritized Sources of Output Data

\begin{tabular}{clc}
\hline \hline Rank & Source & $\mathrm{N}$ \\
\hline 1 & World Bank (2006) & 6081 \\
2 & World Bank (2005) & 586 \\
3 & World Bank (1990) & 359 \\
4 & Groningen (2005) & 953 \\
5 & Maddison (2003) & 4078 \\
6 & IMF (2005) & 93 \\
7 & Oxford (2005) & 41 \\
8 & Country-specific sources & 903 \\
9 & Mitchell (2003a, b, c) & 24 \\
\hline \hline
\end{tabular}




\section{Chilean Defaults and Economic Activity}

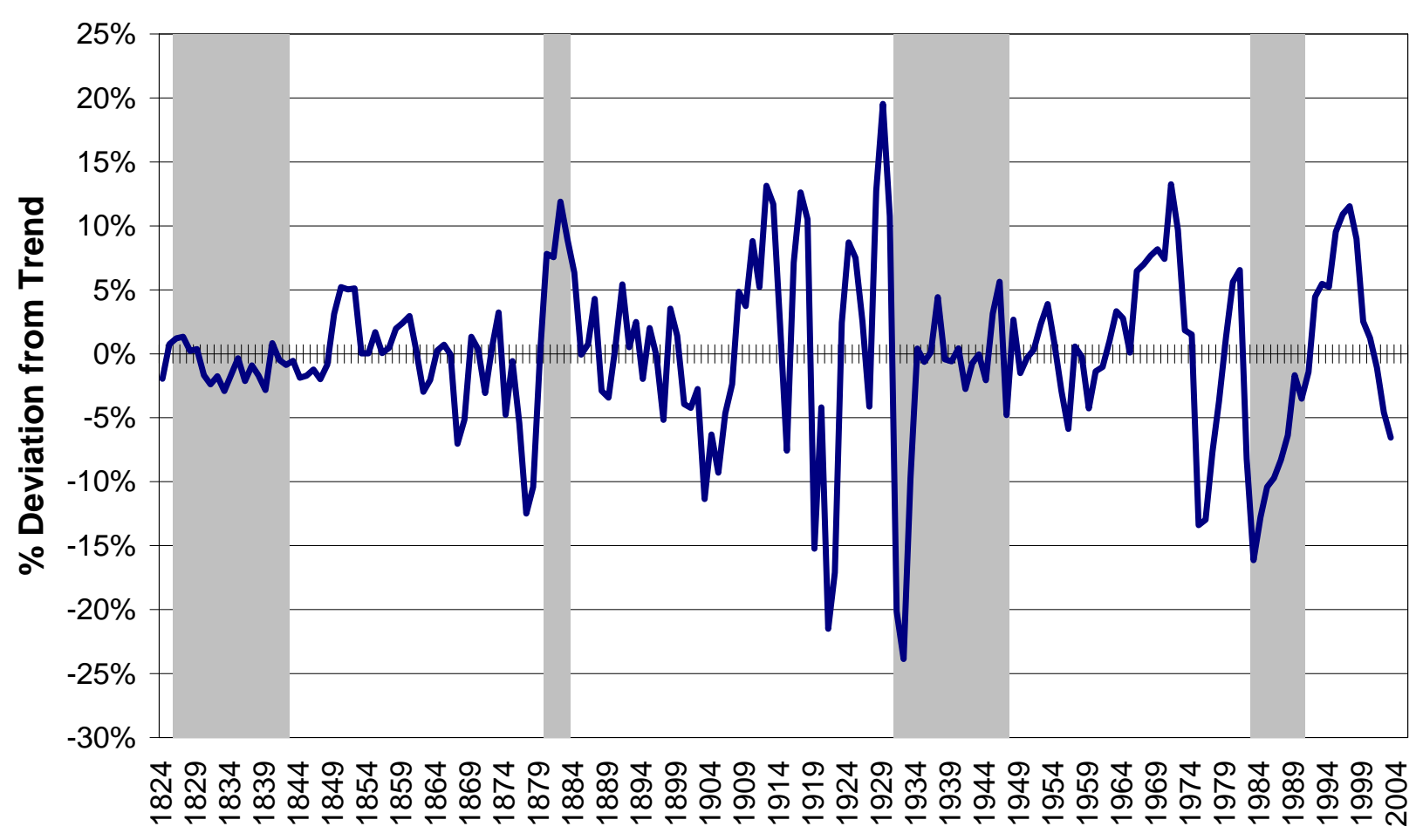

Figure One 


\section{Argentine Defaults and Economic Activity}

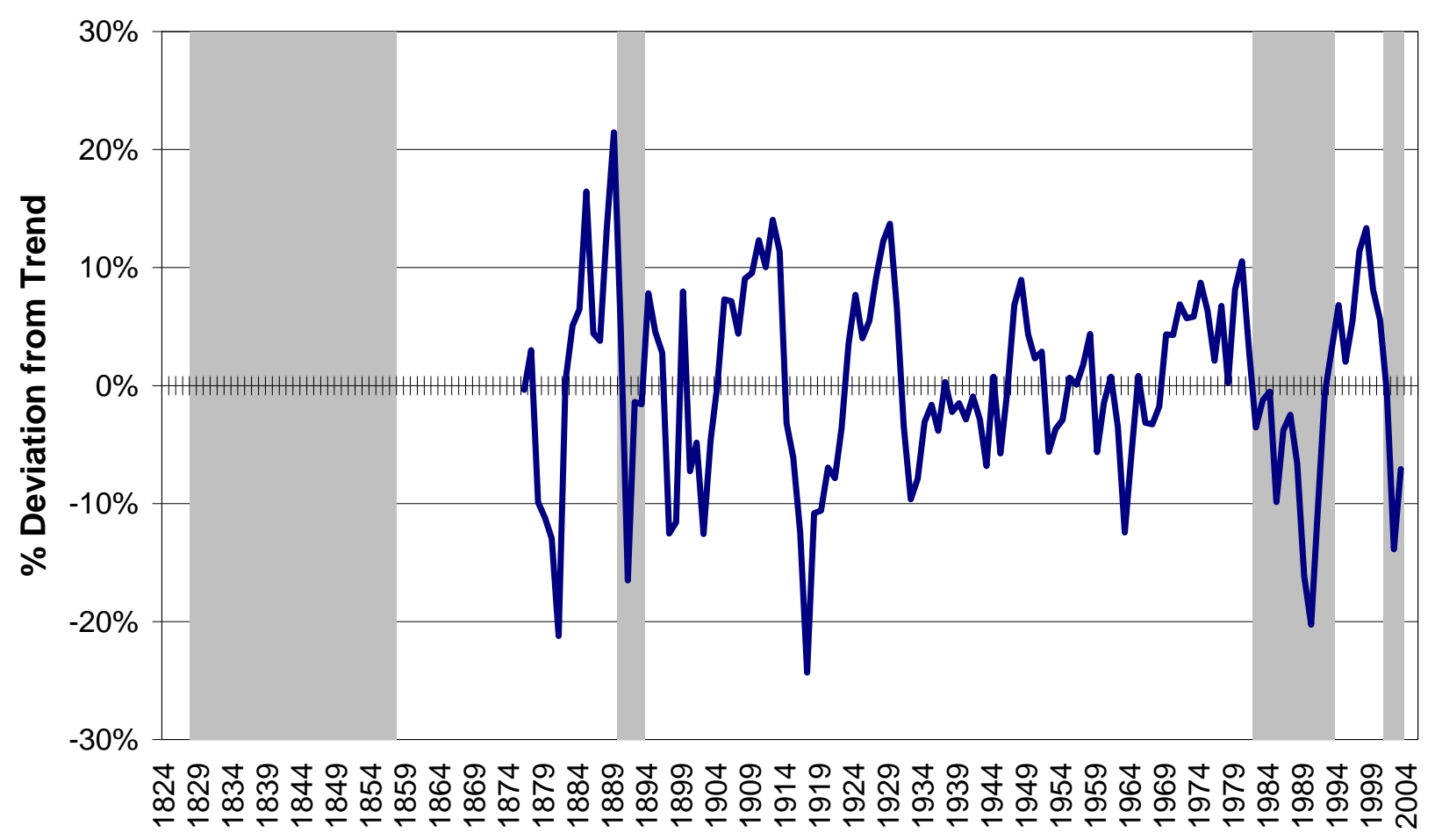

Figure Two 


\section{References}

[1] Aguiar, Mark and Gita Gopinath (2006). "Defaultable Debt, Interest Rates, and the Current Account," Journal of International Economics, vol.69, pp.64-83.

[2] Arellano, Cristina (2005). "Default Risk and Income Fluctuations in Emerging Economies," Unpublished paper, University of Minnesota.

[3] Backus, David K. and Patrick J. Kehoe (1992), "International Evidence on the Historical Properties of Business Cycles", American Economic Review vol. 82, no.4, 864-888.

[4] Baxter M. and King, R.G. (1999), "Measuring Business Cycles: Approximate Band-Pass Filters for Economic Time Series," Review of Economics and Statistics 81, 575-593.

[5] Beers, David T. and John Chambers (2003). "Sovereign Defaults: Heading Lower Into 2004," Standard and Poors, 18th September.

[6] Beers, David T. and John Chambers (2004). "Sovereign Defaults: Set to Fall Again in 2005," Standard and Poors, 28th September.

[7] Conference Board and Groningen Growth and Development Centre, (2006). Total Economy Database, May, http://www.ggdc.net.

[8] Cooley, Thomas J. and Lee E. Ohanian (1991), "The Cyclical Behaviour of Prices," Journal of Monetary Economics vol.28, 25-60.

[9] Correia, Isabel H., Joao L. Neves, and Sergio T. Rebelo (1992), "Business Cycles from 1850-1950 - New Facts about Old Data", European Economic Review vol.36, nos.2/3, 459-467.

[10] Dolado, J.J., Sebastián, M., Vallés, J. (1993), "Cyclical Patterns of the Spanish Economy", Investigaciones Económicas, XVII, 445-473.

[11] Duggan, Catherine, and Michael Tomz (2006). "Sovereign Debt, Defaults and Settlements, 1820-1914." Unpublished paper, Stanford University.

[12] Eaton, Jonathan and Mark Gersovitz (1981). "Debt with Potential Repudiation: Theoretical and Empirical Analysis," Review of Economic Studies, vol. 48(2), pages 289-309. 
[13] European Central Bank (2000), Monthly Bulletin, October.

[14] Giorno, Cl., Richardson, P., Roseveare, D. and van den Noord, P. (1995), "Estimating Potential Output, Output Gaps and Structural Budget Balances", OECD Economics Department Working Papers, 152.

[15] Harding, Don, and Adrian Pagan, (2002). "Dissecting the cycle: a methodological investigation." Journal of Monetary Economics. 49 (2), pp. 365-381.

[16] Hodrick, Robert J. and Edward C. Prescott, (1997). "Postwar U.S. Business Cycles: An Empirical Investigation." Journal of Money, Credit and Banking, 29 (1), pp. 1-16.

[17] Levy-Yeyati, Eduardo and Panizza, Ugo (2006). "The Elusive Costs of Sovereign Defaults." Unpublished paper, Universidad Torcuato Di Tella.

[18] Maddison, Angus. (2001). The World Economy: A Millennial Perspective, Paris: OECD.

[19] Maravall, Agustín. and Ana del Río (2001). "Time Aggregation and the Hodrick-Prescott Filter." Banco de España - Servicio de Estudios, Documento de Trabajo no. 108.

[20] Miller, David M., Michael Tomz and Mark L. J. Wright (2006). "Sovereign Debt, Default, and Bailouts." Unpublished paper, Stanford University.

[21] Pitchford, Rohan and Mark L. J. Wright (2006). "Restructuring the Sovereign Debt Restructuring Mechanism." Unpublished paper, Stanford University.

[22] Sturzenegger, Federico. (2002). "Default Episodes in the 90s: Factbook and Preliminary Lessons," Unpublished paper, Universidad Torcuato Di Tella.

[23] Suter, Christian. (1990) Schuldenzyklen in der Dritten Welt: Kreditaufnahme, Zahlungskrisen und Schuldenregelungen peripherer Länder im Weltsystem von 1820 bis 1986. Frankfurt a.M.: Anton Hain (Ph.D.).

[24] Suter, Christian. (1992). Debt Cycles in the World-Economy: Foreign Loans, Financial Crises, and Debt Settlements, 1820-1990. Boulder: Westview. 
[25] Tomz, Michael. (2007). Sovereign Debt and International Cooperation: Reputational Reasons for Lending and Repayment. Princeton, NJ: Princeton Univ. Press.

[26] Ravn, Morten O. and Harald Uhlig (1997). "On Adjusting the HP-Filter for the Frequency of Observations". Review of Economics and Statistics, 84(2), May 2002, pp. $371-76$.

[27] Wright, Mark L.J. (2002). "Reputations and Sovereign Debt." Unpublished paper, MIT.

[28] Yue, Vivien. (2005). "Sovereign Default and Debt Renegotiation." Unpublished paper, New York University.

\section{Sources for Construction of Output Series}

[1] Banco Central del Ecuador (1997). Setenta Años de Información Estadística. Quito: Banco Central del Ecuador

[2] Braun, Juan, et al. (2000). Economía Chilena 1810-1995: Estadísticas Historicas. Instituto de Economía, Potifícia Universidad Católica de Chile.

[3] Bureau of Census and Statistics (1960). Union Statistics for Fifty Years: Jubilee Issue, 1910-1960. Pretoria: Unie Van Suid-Afrika.

[4] Carter, Susan B., et al. (2006). Historical statistics of the United States, Volume Three: Economic Structure and Performance. New York: Cambridge Univ. Press.

[5] César das Neves, Joao Luís (1994). The Portugese Economy: A Picture in Figures, XIX and XX Centuries with Long Term Series. Lisbon: Universidade Católica Editora.

[6] Commission of Enquiry into the Mining Industry of Southern Rhodesia (1945). Report of the Commission of Enquiry into the Mining Industry of Southern Rhodesia. Salisbury: Printed for the Government Stationery Office by the Rhodesian Printing and Publishing Company.

[7] Cortés Conde, Roberto (1997). La Economía Argentina en el Largo Plazo. Buenos Aires: Editorial Sudamericana. 
[8] Eckstein, Alexander (1955). "National Income and Capital Formation in Hungary, 19001950". In Income and Wealth, ed. Simon Kuznets, 152-223. London: Bowes \& Bowes.

[9] Federal Bureau of Statistics - Pakistan (1997). 50 Years of Pakistan in Statistics. Karachi: Manager of Publications, Statistics Division, Government of Pakistan.

[10] Goldsmith, Raymond W. (1986). Brasil 1850-1984: desenvolvimento financeiro sob um século de inflação. Curitiba: Banco Bamerindus do Brasil.

[11] Greasley, David and Les Oxley (2000). "Measuring New Zealand's GDP 1865-1933: A Cointegration-Based Approach." Review of Income and Wealth 46(no. 3): 351-68.

[12] Gregory, Paul R. (1982). Russian National Income, 1885-1913. New York: Cambridge Univ. Press.

[13] Groningen Growth and Development Centre and The Conference Board (2005). Total Economy Database, January 2005. Accessed May 30, 2005.

[14] Grytten, O.H. (2004). "The gross domestic product for Norway 1830-2003". In Historical Monetary Statistics for Norway 1819-2003, ed. Ø. Eitrheim, J. T. Klovland and J. F. Qvigstad, 241-88. Oslo: Norges Bank.

[15] GRECO (Grupo de Estudios de Crecimiento Económico) (2002). El Crecimiento Económico Colombiano en el Siglo XX. Bogotá, Banco de la República-Fondo de Cultura Económica.

[16] Gunnarsson, Gudmundur (1990). The Economic Growth in Iceland, 1910-1980: A Productivity Study. Uppsala and Stockholm, Sweden: S. Academiae Upsaliensis; Almqvist \& Wiksell International.

[17] Hansen, Bent and Girgis A. Marzouk (1965). Development and Economic Policy in the UAR (Egypt). Amsterdam: North-Holland Publishing Co.

[18] Hoffmann, Walther G. (1965). Das Wachstum der deutschen Wirtschaft seit der Mitte des 19. Jahrhunderts. Berlin: Springer-Verlag. 
[19] INEGI (1985). Estadísticas Históricas de México. Mexico, D.F.: Instituto Nacional de Estadística, Geografia e Informática; Instituto Nacional de Antropología e História.

[20] International Monetary Fund. (2005). "International Financial Statistics CD-ROM." April.

[21] Kostelenos, George C., et al. (forthcoming). "Gross Domestic Product 1830-1939". In Sources of Economic History of Modern Greece: Quantitative data and statistical series 1830-1939. Athens: Historical Archives of the National Bank of Greece.

[22] Lains, Pedro (2003). Os Progressos do atraso: Uma nova história económica de Portugal. Lisboa: Instituto Ciencias Sociais da Universidade de Lisboa.

[23] Maddison, Angus (1995). Monitoring the World Economy, 1820-1992. Paris: Development Centre of the Organisation for Economic Co-operation and Development.

[24] Maddison, Angus (2003). The World Economy: Histocial Statistics. Paris: Development Centre of the Organisation for Economic Co-operation and Development.

[25] Mitchell, Brian R. (2003a). International Historical Statistics: The Americas, 1750-2000. New York: Palgrave Macmillan.

[26] Mitchell, Brian R. (2003b). International Historical Statistics: Europe, 1750-2000. New York: Palgrave Macmillan.

[27] Mitchell, Brian R. (2003). International Historical Statistics: Africa, Asia E Oceania, 1750-2000. New York: Palgrave Macmillan.

[28] Mizoguchi, Toshiyuki and Mataji Umemura (1988). Basic Economic Statistics of Former Japanese Colonies, 1895-1938: Estimates and Findings. Tokyo: Toyo Keizai Shinposha.

[29] Oxford Latin American Centre. (2005). "Oxford Latin American Economic History Database." from http://oxlad.qeh.ox.ac.uk/index.php.

[30] Rankin, Keith (1992). "New Zealand's Gross National Product: 1859-1939." Review of Income and Wealth 38(no. 1): 49-69. 
[31] Schulze, Max-Stephan (2000). "Patterns of Growth and Stagnation in the Late Nineteenth Century Hapsburg Economy." European Review of Economic History 4(3): 311-40.

[32] Statistics Iceland. (2005). "National Accounts and Public Finance." Retrieved December 21, 2005, from http://www.statice.is/.

[33] Yousef, Tarik M. (2002). "Egypt's Growth Performance Under Economic Liberalism: A Reassessment with New GDP Estimates, 1886-1945." Review of Income and Wealth 48(no. 4): $561-79$.

[34] World Bank (1990). World Tables of Economic and Social Indicators, 1950-1988. Paris, Washington, DC: World Bank, International Economics Dept.

[35] World Bank (2005). World Development Indicators 2005.

[36] World Bank (2006). World Development Indicators 2006. 